\title{
Towards Cultural Clash and Hybridity, An Analysis of Bapsi Sidhwa's An American
}

\section{Brat}

* Shamim Akhter, PhD Scholar (Corresponding Author)

\begin{abstract}
Culture is a way of life that takes into its jurisdiction to all experiences of life and social associations. Culture receives variations over time. Similarly, the culture of the Sub-continent is altered with the arrival of the English here. That is why the Literature of this area is called Post-colonial literature. Cross-Culturalism is also a part of post-colonial theory. Its chief aim is to analyze the morphological organization which takes to the origination of the conception. Culturalism indicates the tractability of the self to absorb in the transmission and understanding of spoken and written indications and to react accurately and suitably. The 'cross' in cross-culturalism designates the crossing of the remotest barriers from one make to another. It also reveals the constant growth of borders. People migrate to other countries, lead life by absorbing the culture of that country but they experience problems regarding language and their own culture. The undertaken research aims to reveal the cross-cultural experiences keeping in view Sidhwa's (1994) 'An American Brat'. Sidhwa (1994), explores the differences of cultures that existed between East and West by introducing the character of Feroza. Feroza belongs to Pakistan and goes to America. She finds the culture of America different from the culture of her native country. The undertaken research is an attempt to reveal the description of cultural differences and hybridity through the character of Feroza.
\end{abstract}

Keywords: Culture, Morphological Organization, Postcolonialism, Differences, Jurisdiction,

\section{Introduction}

$$
\text { Culturalism \& Boundaries }
$$

The importance of culture in the improvement of societies and its people cannot be denied during the whole history of mankind. It becomes the driving force for major issues as conflict or war and amity. Its dynamic power excites people to do noble and awful acts. A strong link for personal devotions and faithfulness among people is provided by it. It is often observed when any person sees another person in a particular culture speaking his language and intonation; he is attracted to him and feels a sense of companionship. Shenkar (2008) maintains that it is possible to bridge the cultures, but they cannot be infringed upon nor they can threaten". Additionally, the culture of people infuses specific features and qualities. People of all times and all spaces are affected by its dominant impact.

Moreover, no worldly power shapes people into specific forms and standards so productively than cultures. Its service is more powerful than conventional education because it passes on specific ideas, traditions, and values of one generation to another in an effective way. Culture affects the people and states powerfully and people must understand the culture so that they may be aware of their roles. There is a deep and complex connection between human society and culture because the culture is produced and transferred to others in societies. Isolated persons do not produce cultures. Individuals make cultures when they act and work together and communicate with others. There is no sense of cultural formation like speech and politics without communication of people.

All People have their own culture and tradition. Different People perceive culture differently and that is why it may be explained in many ways. Hofstede (1994) opines that mutual programming of the mind is called Culture which has the power to separate the people of one community from another. Culture is a set of specific worldwide values and has a state of human excellence. It involves mental and creative work which preserves the thought and experience of people in an elaborated way. Culture may be described as it defines a life's specific way which finds its expression of particular meaning and values not only in learning and art but in institutes and common conducts too. It may be said that a way of life is represented by a culture that contains the wholeness

* School of Languages, Civilisation and Philosophy, Universiti Utara Malaysia, Malaysia Email: misschudry96@gmail.com 
of life experience and societal associations. Undoubtedly, people are affected by cultures, and cultures are produced by people. When people receive change, cultures also receive change. In the subcontinent, with the arrival of the English, it becomes the colonial state and the culture of that area has been changed. After getting freedom from the English, people of that area do not get rid of the influences of colonial culture and its power.

Colonialism is a channel that not only brings a change in social and cultural spheres, but it also affects the Politics and economy of that area along with the global market. Said (1994) narrates that imperialism loiters in the places where it ruled, in all fields of life as culture, politics, ideology, economy, and social customs. Consequently, the powers of culture containing the domination of language make it possible for imperialism to be present outside the boundary of a region strengthening the universal idea of the settled without might.

There are many sources of stimulation for these cultural modifications and lineal interference of the imperial state is one of them. After getting freedom, these post-colonial nations face many issues like cross-culturalism, hybridity, identity crisis, and alienation. So, cross-Culturalism occupies a prominent place in post-colonialism. Culturalism refers to the elasticity of the person to involve in the process of exchanging information and understanding of spoken and non-lexical indications and to reply in a pretty or appropriate manner. 'Cross' in cross-culturalism refers to cross the excessive obstacles which are built by one person for another. Continuous enlargement of boundaries is also indicated by it. Zubair (2012) examines that dilemmas of hybridity and identity are attached to immigrants exclusively. Especially the immigrants belonging to the colonized nations experience Diaspora however so far as Feroza is concerned, she feels pleasure in this advanced country and amuses herself with the liberty of this developed state and a liberal culture that is not allowed in her birth society.

The hybridity or crossing of beliefs and thinking points out that culture is unfixed, and crossing happens using interaction or discussion. Ashcroft et.al (2002) maintain that new transcultural patterns create hybridity inside the contact region hybridity shaped by a settlement that links to linguistic, culture, and politics. It is obvious that in a diverse society, people having different cultures discuss their problems in many ways.

Language is a part of the culture and it cannot be separated from it. It obeys the lingual and societal practices which are stirred by cultural standards. All activities of language and non-linguistic from which discursive context is formed require proper attention to perceive. To carry on this crosscultural awareness, Common comprehension may be set up. Such kind of communication or discourse finds its expression in the works of several authors. Not the phrase cross-culture deals not only with language but numerous fields. By chance, a person may be stimulated by the other culture because of living there. He/she adjusts himself in that culture by adopting the other cultural lifestyle and forgetting his/her own culture. Thus, with this discourse, this undertaken research examines Sidhwa's work 'An American Brat'. She is a famous Pakistani literary figure.

\section{Statement of the Problem}

Usually, the word 'culture' stands for many diverse things. Matsumoto (1996) describes that culture is the combination of behaviors, traditions, principles, and standards and the people of a community share these things but different for everyone, communicated from one generation to the next. According to some people, and admiration of good music, food, literature, and art indicate culture. A biologist thinks that culture is the settlement of bacteria. On the other hand, the anthropologists and other scientists who study behavior opine that culture refers to knowledgeable human conduct, practices, and comprehension. Clearly, a particular society is distinguished by culture and its tradition. When individuals talk about the culture of Italy, Samoa, or Japan, it means that common customs, values, and language are indicated which keep these individuals away from others. Culture is not only a structural standard that keeps hold together the whole community, but it is used as a tool to distinguish one community from others. Eliot (1948) believes that three methods are used to study the culture, the culture of the person, the culture of a class, and the third one is the culture of the entire society. He believes that the culture of a group depends upon the culture of an individual and similarly the culture of a group depends upon the culture of the entire society to which that group identifies itself. Thus, this is the culture of the society that occupies a central place.

It may be maintained that culture is a complicated term and comprehension, knowledge, conviction, rules, values, tradition, norms, and all other aptitude and behaviors which a person gains, 
all fall into the category of culture. So, Culture is a term which is applied to a particular, different society and its people and it has a series of customs which are different from other people's customs. It is the possibility that some customs and habits are common between the people of two societies. No doubt, every state, and nation occupies a diverse culture, and frequently inside it, there are different cultural customs. Shades and multiplicity to the human world are provided by the heterogeneity of culture but simultaneously people are segregated into several groups and subordinate groups who share a few common things, and, in this way, it becomes a big hindrance for human associations. Sidhwa's novel 'An American Brat' explores the dilemma of cultural clashes and the issues which it gives birth. Kani (2013) points out that this writing of Sidhwa (1994) throws light on the transformation of an exile. Feroza has a desire to live in America but after spending four years in the USA, her priority is going back to Pakistan. So, the present study explains how Feroza finds the culture of America strange and how tries to adopt this culture.

\section{Significance of the Study}

Sidhwa (1994) investigates the issue of the cultural clashes in her fourth novel in detail. Sidhwa (1994) says that the subject of 'An American Brat' obviously deals with culture-shock. Hussain (1993) says that the theme 'cultural shock is handled in 'An American Brat. She says when people from the sub-continent migrate to western countries for studying, they meet with cultural shock. But the clashes in culture cause hybridity. Imtiaz (2011) elaborates that Diasporic communities want to have similarity along with difference with the cultures of the countries where they migrate to. It is responsible for hybridity and syncretism. When people of South-Asia migrate to western countries for education and employment, they have to face culture - shock. Bhaba (1994) explores the disparities among cultures that form Hybridity as 'in-between 'or 'interspaces.

This novel elaborates that western culture and its customs are opposite to the customs and culture of the East. Khan (2006) perceives that multiculturism is not multiculturism in any respect. The people who belong to Asia are generally taken as backward and stupid. When these people migrate to Western countries, they find two roads to choose, to remain stupid or backward or to be modern by absorbing the western culture. The undertaken novel describes the story of a young girl who experiences three cultures, Parsi culture which is the culture of her community, second the Muslim culture of Pakistan that is her native country and third is the culture of America where she is sent to seek education. Kumar (2016) presents his views about "An American Brat" and says that cultural difference is the malediction of this writing which elaborates the differentiation in a skilfully way between two cultures---Parsee and Jewish. He illustrates that Feroza's character shows a witting transformation from conventional to multinational and from religious clannishness to the theological doctrine that all people will eventually be saved.

An American Brat depicts how does the young girl, Feroza understands her Parsi and other cultures which show differences. Her journey to the USA, her education, and her conversion into a grown-up and sensible lady become the most important part of the book. Mishra (2015) maintains that a small group of people experiences any issues as identity crisis, dislocation, hybridity, etc. due to cultural clashes regardless of the fact in which country this small group of people lives. The novel presents the change which Feroza experiences in the USA and by experiencing this change how are her views about life altered.

The conducted research is significant as it highlights the differences present between East and West. In the global world where all nations, countries, and communities come closer to each other and all are affected by others' culture, language, fashion, and civilization. This trend results in hybridity. The researcher investigates hybridity and the problems which it creates.

\section{Research Questions}

(1) Which factors are responsible to create hybridity?

(2) Why do immigrants find western culture and set of values aliens?

(3) How does Western culture appeal to Feroza?

\section{Literature Review}

All individuals possess specific cultures. Generally, culture affects the individuals preserved in their homes. The people experience a distinct culture when they move to a new place by leaving their home place and in this case, cultural acclimation is needed. This acclimation leads to hybridity. Transcultural forms create hybridity and it is a situation that produces new unique persons. Then hybrid identity is generated by these people. Jackson (2008) investigates that the concepts about 
hybridity inform us about the patterns of cultural deriving. While it is obligatory for crossbred persons to blend in with their milieu and identify the diverse cultural structures where they work, they frequently unintentionally attain certain cultural traits that become part of their own cultural identity which is called a hybrid identity.

Immigrants' first generation's dealing with hybrid identity can be different than the second generation's dealing. It is observed that the first generation of immigrants receives more impacts of old culture than the second generation because the second generation is affected more by the new culture. Diversity in culture may take them to the cultural clash. Nedumchira (2009) asserts that after arriving in a new country, immigrants experience alien milieu, traditions, and culture. In this case, their sense of losing themselves is at stake. Cultural clash and hybridity is a world-wide phenomenon and it has gained great fame in this age of globalization. Tomlinson (1999) expresses that globalization is the network, which is growing speedily, and it is a network of interconnections and interdependencies that depicts modern social life. Post-colonial literature is replete with authors whose works give glimpses of hybrid identity and cultural clashes. Almost all post-colonial writers try to throw light on this dilemma.

Hamid is a Pakistani writer. He got his early education from Lahore, Pakistan, and then went to America for higher education. He graduated from Princeton University and worked in a consultancy firm. He inclines to write. So, he has written many books. Being non-native, he has faced many challenges in America. He attempts to explore these challenges through his writings. Among these challenges, cultural clash and hybridity occupies a prominent place and finds its expression in his famous work, namely "The Reluctant Fundamentalist" (2007). Hamid (2007) beautifully explores the issue of cultural clash that leads to hybridity.

Hamid (2007) illustrates the relations between the cultures of America and Pakistan by highlighting the perspective of neo-colonialism. He says that even after getting freedom, developing nations are still influenced by the American neo-colonialism which directly affects the people, their cultures, and their individualities. People are used by him as a symbol to represent their societies and cultures. Hamid (2007) introduces the character of Changez to present the dilemma of cultural clash and hybridity. Changez is a Pakistani - Muslim who goes to America for getting an education and a bright future. In this pursuit, he merges himself completely in the neo-colonial culture of America. But his effort of adopting the American culture becomes futile because he cannot become an American. He loves Erica, a white lady who is not ready to forget her dead lover Chris. After his death, he affects Erica's identity. Erica's wearing of her dead boyfriend' T-Shirt shows the strong connection that is present among the people belonging to the same culture. Changez is not accepted as a lover by Erica and her parents due to his belonging to a different culture.

Hamid (2007) endeavors to explore the clashes of the culture of East and West. He believes that Changez and Erica's relationship does not develop because they belong to two different races and cultures. The clash in cultures keeps them apart and makes them two different worlds. Changez tries his best to win her love. He becomes Chris by quitting his name, individuality, and culture. When he pretends to be Chris then the white lady gets ready to accept him. Hamid (2007) conveys this hidden message that the Americans accept the non-American on this condition when they fully quit their identity and culture ad accept the superiority of American culture.

Kane (2004) talks about cultures and is interested in his own culture. He is aware of the fact that what they have possessed historically from colonization has to be domesticated and considered an essential element of their culture. Kane (2004) opines that clashes in cultures create diversity and this diversity can be seen prevailing in the world. Kane is an African author and he says that today's world is divided into distinct groups. One group can be called modern and others can be called traditional groups. The modern group believes that cultures should have universality whereas the other group believes in extremism and cultural clashes. He investigates that diversity is not an abnormal thing, but it is the fact and truth of the world.

Varner and Beamer (2011) explain that in this era, the culture of no society is pure and the whole world is becoming rapidly intercultural. The people come to other country having a distinct culture, values and start living there irrespective of the fact that their cultural background and value system is different. Varner and Beamer (2011) maintain that the whole world is attempting to arrange with the increasing diversity of the people. The reason is that several immigrants migrate to other countries to seek shelter and employment. The migration of people to other countries has been 
increased due to globalization. But there are still some nations who try to keep safe their culture against the culture which is brought by immigrants. Varner and Beamer (2011) opine that culture is not merely a set of human traits but also the wealth and ownership of a group of people. It is argued that it is a culture that gives shape to society. Correspondent experiences of life and cognate elucidation of what those experiences mean are responsible to give it shape. No doubt culture is cerebral software and it explores the realism of the mind. It starts teaching us from our early days about different issues and guides us on which matter we should adopt and which not. It may be maintained that culture is created within society and it is a society that supplies sensation to the thought of culture.

Moreover, Varner and Beamer (2011) say that when a person is born, he has no culture. He gains his culture, cultural system, norms, values, traditions, and principles from the day of his birth. So, culture is something that can be gained, and this gaining assumes vital importance for immigrants when they migrate west countries, especially the USA. Going to another country for a person means understanding along with observation of cultural disparity for the first time in his life. Varner and Beamer (2011) state that there is no similarity between two cultures, whereas the cultures of different nations may share inevitable or certain customs or standards and at the same time, these cultures have such things that make them different and create disparity among cultures. Varner and Beamer (2011) argue that it is the culture that enables the person to understand the world. They argue that people who are different by having different cultures, culture defines that in what way they have to behave and observe the world. It is explained that Culture is the astonishing production of human contrivance (imagination) mind and it helps the people to observe the disparities. Nonetheless, it is difficult to discuss and frequently it arises feelings of confusion, tension, dislocation among people and they find themselves in a fix to answer the question from where they belong.

Yoseph (2005) defines that it is not only an issue of corporal dislocation when a person migrates from one country or culture to another country or culture, but it is an issue of internal or mental experience. Dissimilar spaces generate diverse experiences and all these factors play their role in producing distinct recollections. And remembrance occupies a noteworthy place in the building of individuality. Cultural hybridization is the outcome of the experience of migration between dissimilar cultures.

Etoroma (2006) illustrates that homelessness and isolation are the lasting heritage of globalization and they further lead to the dilemma of identity. All nations are attempting to have more intercultural surroundings. Within this continuously growing organism, some people do not keep pace with the world and remain behind and many people are cast away regarding them strangers based on differences in culture. Issues are observed globally mainly due to clashes between the rights of a person and the rights of a civilian. It can be said that if a man is not a citizen, he is not entirely a man. A man is recognized as a man when he is a citizen. To be a man is conditioned by citizenship. Etoroma (2006) maintains that the word stranger or foreigner is a scratch mark (scar) between the man and the citizen. In the era of globalization, easy traveling across the world can be made due to intercultural communication and understanding. At the same time, global societies need to know the differences existed among cultures. This knowledge enables us not only to perceive other cultures also helps us to perceive our identity.

Brennan (2008) makes an interesting study on different cultures and he uses the word playground for today's global world where people having distinct cultures are found struggling in the Self/Other. And their struggle results in problems. The author states that the present world is presenting a distorted or vague image of self or individuality. Not only people are affected by the phenomenon of Globalization, but this gigantic phenomenon takes into its grip all fields of society as technology, electronic and print media, and even traveling. Brennan (2008) argues that the world is being rebuilt being a sole collective space. It may be maintained that the world tends to be more homogenized which leads to the production of an individual crossbreeding world culture where deviations in nations' traditions, values, tastes, and experiences are shown at a lesser level.

Hall (1996) says that recognition is a production, a procedure which is never accomplished, it always remains active. It is not clarified that it may always be 'acquired ' or 'lost', continued, or discarded. So, recognition is a course of expression, over- firmness, or a deficiency, but always an improper course. It is argued that the process of identity construction always remains active and is never fulfilled. A person and his setting are continuously varying and since people's settings form 
them, their individualities to all times are altering. Hall (1996) says that identity is not ' being' but more about 'becoming'. He opines that it is identity 'who we are' or ' from where we belong' but it is what we want to be and in what way, we act. Identities do not represent the outer surface, but they are formed inside. This concept highlights the significance of the societal environment in the construction of identity and identification is required to make one's own identity.

Imbert (2004) examines globalization and its impact on the modern world. He says that globalization gives more importance to differences among people rather than similarities. The author maintains that given much importance to diversities, the issue of dislocation is created for many people. They always remain confused and not know where they belong.

Sarup (1994) illustrates that the identity of a person is connected with the surrounding where he lives. That is why; a person's identity is always varying due to change in the environment. $\mathrm{He}$ stresses the concept of home and says in what way, the feelings of home are produced. He throws light on the factors which create differences between stranger (outsider) and native (citizen).

\section{Theoretical Framework}

Ashcroft et.al (2002) maintain that new transcultural patterns create hybridity inside the contact region and hybridity is shaped by the settlement that links to linguistic, culture, and politics. But some researchers also favor the positive aspect of Hybridity which gives rise to a new form of culture. Some researchers like Imtiaz and Asif (2011) are in favor of hybridity. They opine that it creates a new type of hybridity. According to Imtiaz and Asif (2011), Hybridity does not deprive immigrants of their rights of colonizes caused by globalization whereas a novel type of culture is come forth because of it which is formed by the immigrants and it empowers them. Hybridity' role cannot be denied in shaping a new individuality created by the cultural clash. Bhaba (1994) explores the disparities among cultures that form Hybridity as 'in-between 'or 'interspaces.

Cultural theorists like Bhabha (1994), Hall (1996), and Ashcroft et. al. (1995), argue that as languages performed a significant role in the production of the empire's communications enabled the administration of previous European societies to ensure the smooth running, thus texts and languages also play an important role in the historical reformation of national accounts and in the process of remaking the individualities of the previously occupied population. Many social theorists have raised questions about the classification of culture and often it expresses rigid classifications of unquestionable conduct. Many authors and theorists devise a variety of new nomenclatures and conceptions of culture. While discussing the cultures, in his seminal, Street (1993) "Culture is a Verb" maintains that we have a tendency essentialize the classes and explanations we make, and he keeps on saying that it is beneficial to know what function culture performs in place of defining what is culture. The aim of examining culture does not explain the culture and to accept that explanations but its function is to gain knowledge on how and in what way, these definitions are created, and which type of situations and causes are responsible to make these definitions. The concept of 'third space' and hybridity has been formulated by Bhabha (1994) where diversity is neither One nor the Other but something else besides that is in-between.

While Pennycook (2007) argues that the word hybridity gives a powerful expression of colonial partial tones of amalgamated species. The term hybridity is used to insult and show the uncleanness of the amalgamated races in discourses of colonialism. Bhabha (1994) raises the question of whether words should only be used with a clear and harmless history or essentialist standards of identity should be questioned by adopting and then overthrowing their lexicon. Bhabha (1994) opines that the third space of hybridity is an uncertain location where the significance of culture and depiction do not possess the initial harmony or stability. so, Bhabha (1994) argues that hybridity or third space is a disturbing and inquisitive space of novel shapes of the meaning of culture and construction which confuse the restrictions of present boundaries and take into account the constituted classifications of culture and individuality. Pennycook (2007) initiates and complicates the concept of transcultural activities by reviewing the conventional concepts of culture. An act to observe the 'trans' instead of 'post' speculations, though, changes the connection from earthly to a more spacial realm, from moment to motion by altering reliance away from a previous set of speculative paradigm to a more current display of backgrounds. The move from the worldly to the spacial is significant for a shift to comprehend the globalization, motion, and relations. Pennycook keeps on maintaining that misconduct does not only mean to leave the established clash, but it also explores the bounds of consideration. The concept of disobedience flees from the bounds of logical 
thoughts and evolves a connection of planned addition inspiring us to feel or consider which has not been felt or considered. Sidhwa's (1994) Feroza shows the third space. She lives in the USA, travels, and spends her time between the USA and Pakistan. Feroza experiences the crises of identity because she closely observes the leading culture, verbal communication, values, and freedom but she remains conscious of the cultural differences.

\section{Analysis and Discussion}

In 'An American Brat', Sidhwa (1994) examines the disparity between Pakistani and American culture and civilization. For exploring the disparity, the author introduces two characters, Feroza and Manek Feroza is the central character of the novel and Manek is her uncle. Zareen's brief stay in the USA also throws light on the differences between the two cultures. Sidhwa (1994) points out the features of the cultures of both countries and also shows how to do the features of each culture show clashes against the features of other cultures. It is admitted fact that today, the world has been expanded and the concept of the border has become borderless. Owing to globalization, several increases in migration has been recorded. The individuals are going to other states by the dispersion of language, culture, and lineage. By keeping in view, the picture of the present world, Literature is taken as a powerful medium to investigate the sufferings and experiences of these people. Literature does not only portray their experiences and sufferings but also shows how do they make decisions as far as their country and host country is concerned. The same medium has been used by Sidhwa (1994) to examine the problems of immigrants. Her work beautifully presents the issue of hybridity which causes cultural clashes. The main character of this novel is Feroza. The study of this book shows the disparities between two opposite cultures, eastern and western culture. Feroza is captured between two distinct cultures.

Sidhwa (1994) explores many traits of the society of Pakistan. The novel is set both in Pakistan and the USA. This is an era when Zulfikar Ali Bhutto is in prison and Islamic fundamentalism is developing in Pakistan. So, Feroza's mother wants to stay away from further impacts of Islamic customs. Feroza is influenced by Islamization during the age of Zia. She also worries about the dressings of her mother who belongs to a middle-class Parsee community. Feroza is a teenager and at this age, she is becoming conservative. The reason behind her backwardness is the Islamic setup and government of Pakistan. Feroza's backwardness reaches this point that she does not answer the phone call. She objects her mother's modern wearing. Women wear their dressing conservatively according to Muslim theology. But Feroza's mother follows her community way of dressing. She tells her mother to wear the dress some more conservatively and she likes the company of her old-fashioned grandmother. Feroza does not like her mother's dressing when she comes to school to pick Feroza and Feroza seriously objects on her mother's wearing and asks her to come to school by wearing a proper dress. She objects her mother's sleeveless sari-blouse, but her mother is amazed to hear these comments and says that they are Parsee, and everybody knows that they dress differently. Here the reader or an individual can understand that every religion and caste has its own culture and tradition. Zareen is worried about this situation because Feroza reflects backwardness by objecting to her mother's dressing.

Zareen opposes the instructions and laws imposed on women in Zia's reign. Zareen fears in this situation and finds Zia's regime terrifying. Zia is in favor of the promulgation of Islamization. In this situation, the women are asked to observe purdah especially to cover their heads with dupattas. Every field of life is influenced by politics and religion. Feroza is being affected by this milieu. Therefore, her parents decide to send her the USA. Her parents think that her views will be changed and widened because of traveling abroad. Other members of Feroza's family do not like this decision and they call it an insolent decision. But on the other hand, Cyrus, Feroza's father, gives his consent to sending because he is well aware of the fact that her daughter has no courage to speak with boys. Feroza's timid nature forces him to have such views.

Sidhwa (1994) states that fundamentalism and politics are the major problems of Pakistani society. Sidhwa (1994) wants to create awareness that people suffer from psychological issues because of fundamentalism. Zareen wants to stay away from her daughter from this situation and decides to send her daughter to the USA. So, her parents decide to send her the USA. Zia's government makes and imposes tight rules for females but ignores the male gender in this regard. Under the rule of General Zia, Pakistani religious fundamentalists have made strict rules for women. Women are supposed to lead their lives conservatively whereas men are allowed to enjoy and lead 
their lives as they want without any restriction. Politics and religion of native place play an important role in Feroza' traveling to the USA. Feroza's grandmother does not like the decision of sending Feroza to the USA and she talks about Islam mostly she disapproves of her daughter's decision but Zareen replies that this milieu is spoiling Feroza. She keeps on saying that Feroza is affected by Islamization and she mostly talks about Islam. She even raises questions about her mother's dressing.

It may be argued that Feroza's journey to self-Consciousness initiates her trip to the USA; basically, it is a turning point for Feroza, and it proves a journey from innocence to maturity. Flight of the plane shows a shift from one culture and civilization to other cultures and civilizations. Stopping of the plane at the different airports of different countries, departure of boarded passengers, and arrival of new passengers show the replacement of cultures for cultures and Feroza's preparation to face the strange culture with the unusual background and environment.

At the airport, she faces the biased due to the tag of the third world where she is investigated without any reason and she is made fun. She is a newcomer and finds this environment unfriendly. She faces the embarrassing distrust at the airport which traumatizes her honor and makes her the target of prejudice and degradation being a citizen of third world nations. She is shocked to face this situation and she shouts: "To hell with you and your damn country. I'll go back."(58 1994). It throws light on the disparity between two conflicting cultures. Her parents send her USA to her uncle, Manek who is studying in America. So, he knows America and its culture fully. In light of his experiment, he guides her niece. He also faces humiliation and disgrace in America being a citizen of the third world. His continuous remarks about Feroza's "desi behavior and third world attitude" shows that he has undergone this situation. After facing many disgraces and sufferings in the USA, he has altered fundamentally as is elaborated by the text:

"A kind of cultural metamorphosis is that had taken place on a psychological level.

He had weathered the trauma of cultural shock after cultural shock, the new world

had buffeted him with emerged toughness." $\quad(119,1994)$

Sidhwa (1994) argues that the family system is very influential in Pakistani culture and civilization and parents' orders are considered to be authorized and children are bound to obey their parents. Zareen is answerable in front of her mother Kuttibai regarding her decision to send Feroza abroad. She enquires Zareen about her decision in a very satirical manner. Kuttibai is against sending her USA and she gets angry with Zareen about this matter. She says that she does not bother to consult with other relatives and elders. But now nothing can be done. So, she instructs Feroza how to behave in America. Feroza is advised by Kuttibai to follow the values of the Parsee community strictly and never get corrupted in the USA. Feroza acts upon the instruction of her grandmother during traveling but her personality is altered inwardly and outwardly as her feet touch the land of opportunity. When she arrives at Kennedy Airport, she feels herself successful and her face glows with happiness. By seeing the organized flow of traffic, the crowd of people, the lights, gigantic building, outstanding neat and clean environment, and well-polished floors, she becomes astounded.

Sidhwa (1994) believes that religion and morality are the significant features of Pakistani culture and civilization. In Pakistan, nobody can compromise on the matter of religion and morality. Religion and moral values occupy a supreme place in people's lives. Almost every matter of life is influenced by Religion. Feroza wants to marry David, non- Parsee boy but she is opposed strongly by her family being a non-Parsee boy. Religion creates hindrance in her way of getting married to David. David gets consent from his parents to marry Feroza even though Feroza is non-Jewish. But Feroza's mother does not allow her to marry a non- Parsee and she is worried that Feroza's children will be taken as unlawfully begotten in case of her marriage with non- Parsee as is elaborated by the text:

"She would be branded an adulteress and her children pronounced illegitimate.

She would be accused of committing the most heinous sacrileges." $\quad(289,1994)$

Sidhwa (1994) narrates that women are not independent in Pakistani society. They depend on men economically, emotionally, and psychologically. Sidhwa (1994) throws light on the problems and conditions of women in Pakistan. They have no freedom to lead their lives according to their own choices but on the other hand, men enjoy liberty. So, she introduces the character of Zareen who thinks about the uniformity of both genders. She wishes that women should be treated likewise, men. She wants to make herself equal to her husband apparently and her wearing heel shows her desire for 
equality. "To measure up to my husband" $(10,1994)$. Sidhwa employs the term 'high heels' which stands for the searching of a man for getting equality.

According to Sidhwa (1994), sexual freedom is not allowed in Pakistani culture openly. In Pakistani society, parents want to stay away from their children from sexual perversion. Kuttibai is worried because Feroza is going to a country where sexual freedom is common, and children can enjoy sexual freedom easily. She discusses with Zareen that the USA is a dangerous place for girls as far as their honor and lives are concerned. Girls are killed after molestation. Sidhwa (1994) shares with us many examples of the exploitation of women in a developed country, the USA. Kuttibai wants that parents should get married to their daughter as soon as possible. She is of the view that parents should not focus on the education of their daughter. That is why she is against the decision of sending Feroza to the USA for studying. She expresses her fear that the USA is harmful to girls. She keeps on saying that she will be liberal, bold and may enjoy the company of drunkard, bad persons, and marry any person regardless of religion. The following lines of the text reveal her fear:

"The there-was pregnant with unspeakable knowledge of the sexual license allowed

American girls and ..... molest, and murder young girls." $\quad(30,1994)$

Feroza feels hesitation and nervousness after reaching America but sometimes she finds changes in her personality and becomes bold, confident, and liberal.

Zareen is surprised when she comes to know about the company of Feroza and her stay with a boy. She is astounded to know about lesbians as is highlighted by the text:

"What goings-on! Feroza was living with a boy and a couple of lesbians." $(300,1994)$

Sidhwa (1994) argues that in the Pakistani system, children are not only forced to obey their parents' orders but relatives too. Children cannot deny their elders' orders. After staying in the USA and enjoying the freedom of America, Feroza expresses her dislike for the family system in Pakistan and answering before parents and other relatives. Sidhwa (1994) investigates that in Pakistani society, it is common to advise the children whether they are Hindus, Muslims, and Parsee. Feroza observes this thing minutely and feels that American society is free from this thing

\section{American Civilization}

According to Sidhwa (1994), Pakistani and American culture and civilization are different in the sense that Pakistani society gives much importance to religion and every matter of life comes under the jurisdiction of religion, but Americans have flexible views about religion. American religion is a personal matter of people. That is why David is allowed by his parents to marry a non - Jewish girl. They do not feel ill that their child is going to marry a Parsee girl. Whereas Feroza has to get permission from her family to marry David. She writes a letter and also sends a photograph of David. It is like a bomb blast on her family and soon Zareen wants her to get back from the US. David starts to call Feroza as 'ZAP' which means Zoroastrians and she calls him 'JAP' which means Jewish. Whereas Feroza's parents are not ready to allow her to marry non- Parsee boys and Zareen goes to the USA to stop the marriage. To hear Feroza's marriage news, her family and relatives show extreme response and behave oddly. To marry a Jewish boy, David raises perturbation and discussion among family members of Feroza back in Pakistan. The elders register extreme responses whereas the young people try to convince them by arguing that it is not a big issue because now circumstances have been altered. They wish that their elders should change their thinking and get rid of backward notions. They want their elders to throw away the array of old concepts by widening their thinking and allow their children to marry outside of the caste and religion.

Sidhwa (1994) investigates the sensitivity that women belonging to the Parsee community do not enter the fire temple to worship in case of marrying outside of the Parsee religion. Zareen goes to the USA to stop her daughter from doing so. She argues that her marriage will be celebrated in case of marrying within religion but in the case of marring non-Parsee, she will be cut off her family and relatives.

Sidhwa (1994) narrates that Pakistani women are dependent on men but in America, women are free and independent. Sidhwa (1994) portrays the character of Joe, Feroza's friend to show the freedom of women in the USA. While the character of Feroza shows the dependence of Pakistani women on men. Americans are free in making decisions and this thing is opposite to the Pakistani culture. In Pakistan, children especially girls are not allowed to take their own decisions. In Pakistan, women are not allowed to do jobs as she wants to do in the USA as is revealed by the text:

"There were no waitresses in Pakistan, only waiters. Since there were no bars 
tenders. Even had the jobs been available and the stigma attached to them had not existed." $\quad(216,1994)$

Sidhwa (1994) throws light on the activities of the women of the Subcontinent. They are expected to stay at home and serve their family. But Feroza decides to do a job being waitress with the help of her friend Jo. Her decision is opposite to eastern culture but she has changed her lifestyle and become the spokesperson for modernity.

Sidhwa (1994) says that in America, the family system is different from Pakistan. The family system is broken. Parents and children mostly do not live together. Children are not bound to obey their parents. Sidhwa (1994) introduces Miller's family to throw light on the American family system. Miller is Jo's father. He runs his restaurant, but his children do not live with him. Feroza is glad to meet with Miller's family and is much impressed by their lifestyle.

Another cultural clash between the two countries has appeared when she gets knowledge about the foresting and raising of children. She finds it different from the Pakistani system. She finds the American way of upbringing entirely different. She is informed that children are raised in the country farms for a fee as the text reveals:

"It was so unlike anything in Pakistan. She had never heard of children being sent to foster homes." $\quad(212,1994)$

Sidhwa (1994) opines that in America, politics does not affect the lives of people so much as in Pakistan. In Pakistan, all and sundry are influenced by politics and its policies. The reason is that in Pakistan, politics does not operate smoothly. Whereas in America, people are not disturbed and effected by politics because of its smooth running. Feroza observes no change in Jo's life because political change does not affect the people of America and they have no concern with politics but in the case of Feroza, she keeps herself aware of the political affairs of Pakistan during her stay in America. She is amazed to hear the news of Bhutto's hanging. She is not happy with her family because they do not update her about the current political situation of Pakistan. Feroza finds that in America people just care about their jobs and livelihood instead of discussing political matters.

Sidhwa (1994) points out that Americans reflect differences in customs, values, fashion, and ways of living, speaking, acting, and eating. Feroza struggles much in learning Americans' manners to adjust to American society. She tries to behave as Americans do. She adopts their manners of eating and deals with salesmen as native. When she arrives in the USA, she stares at the lovemaking couple with the open mouth but after sometimes, she learns how to look at them. Feroza completely adapts and changes her lifestyle to the American lifestyle. She acts, talks, and dresses like an American girl. She learns driving, drinking, dancing, and uses the American slang. The shy natured Feroza turns into a confident and self-assertive girl. When she comes to the USA, she normally acts like an idiot person belonging to a Third World nation. She wears inappropriate dresses for college and becomes an object of fun among college students. Her attempt to open the tin is also ridiculous. She is made fun of by Manek because of her 'desi' pronunciation and idiosyncrasy. He asks her to behave properly and not gaze at people. Once Feroza goes to a store to buy something and creates fuss there because she does not know how to demand a selected item to buy. She says to the sales girl that she wants to have this, but she replies that she cannot take it because it is not a charity home. She keeps on saying that she may take this after paying its price.

Sidhwa (1994) explains that no one meddles with others' affairs in American society. People find themselves free in making decisions. They do not accept interference from any person in their decisions and even religion cannot stop them from making any kind of decision. David decides to marry Feroza, a Parsee girl, without seeking permission from his parents and without consulting any religious intellectual. Whereas Feroza who belong to Pakistani culture, she has to seek permission on every level. But over time, finally she becomes independent and takes decision herself without the interference of others.

Sidhwa (1994) believes that America is a land that provides equal chances of progress for every person. Nobody snubs others' rights. The American culture allows everyone to go for equal progress. No suppression and reversion is found in American society at any level. Any person can earn money because of intelligence by using all means that are allowed in American culture. Feroza informs her family and relatives about the circumstances of America when she comes back to Pakistan to meet her family. She explains that poverty can be seen in America but it is amazing that the poor immigrants avail the basic facilities of life as power supply, pure water, and car. She thinks 
that in Pakistan, the poor are unable to have a bathroom. Sidhwa (1994) through Feroza highlights that America provides equal opportunities for all people because of its nature of multiculturalism. Feroza receives impacts of the cross-culture which transforms her into an independent, bold, strong, and non- religious person. When Feroza experiences two different cultures, her mindset receives many impacts. She becomes liberal and advance. Her liberty and mental advancing are reflected in her relationship with David. Her physical relation with David shows her liberty. Often, she wonders to see what she is doing and the final part of the novel reveals her thoughts in the following words:

"Once when she was sneaking back into her room at three o'clock in the morning with her shoes in her hand, she wondered if she was the same girl who had lived

in Lahore and gone to the Convent of the Sacred Heart." $(264,1994)$

Sidhwa (1994) narrates that it is the impact of American culture that Feroza becomes confident and independent. With the help of an American friend Jo, the reluctant and traditional Feroza changes into a self-assured, confident, and bold. She behaves as an American girl. She discards all the customs, culture, and traditions of her native country within days.

When she is in Pakistan, she does not decide that she wants to perform in a play or not in a College function. But during her stay in the USA, she is a different person. She takes her decision by own and takes admission in university confidently. She is bold enough in selecting her profession and choosing friends. Not only these, but she also decides to marry a Jewish boy and does not hesitate to develop relation with him.

Her style of talking is very artificial in the beginning when she arrives in the USA. When she talks to others, they regard her odd and artificial due to her pronunciation and selection of words. She improves her accent and makes it almost perfect as natives with the help of her friend Jo.

Jo brings changes in Feroza regarding her accent, wearing style and mannerism. Almost all Feroza's life is influenced by Jo's guidance. With the help of Jo, Feroza becomes accustomed to say "Gimme a lemonade. Gimme a soda" (p.154) in place of saying "May I have this - may I have that?" (p.154). It appears that Feroza is becoming dappled as Lacan (1994) argues that camouflage is the impact of imitation. It has no concern with the harmony of the background, but it is against the dappled environment.

Sidhwa (1994) shows that Feroza endeavors much to alter herself and to bring modifications in her personality to attain the camouflage of American culture and surroundings. She starts to absorb the American ways of culture as she initiates the darting motion with boys in America. This type of activity on the part of women is unknown in Pakistani culture but is common in American culture. Feroza' endeavor of reconciliation with the background is explored through flirting boys. Bhabha (1994) illustrates that this facet of mimicry reflects the disparity which is the act of rejection.

\section{Conclusion}

Sidhwa (1994) tries to highlight the differences between Pakistani and American cultures. Sidhwa (1994) concludes the discussion of opposite cultures by quoting Zareen's two opinions. Zareen believes that the cultures of Pakistan and America are not perfect and flawless. These cultures show opposition against each other and Feroza's personality is fully transfigured because of this fact as is highlighted by the text:

"She's becoming more and more backward every day." (9, 1994)

"I should have listened. I should never have let you go so far away. Look what it's done to you - you've become an American brat!" $(279,1994)$

Sidhwa (1994) exposes the confusing picture of the cultural mixture by introducing the character of Feroza while staying in the west. In post-colonial discourse, Diaspora and Hybridity are the two main notions that occupy a great place in post-colonial discourse and they also pave the ground for the dilemma of identity in which Sidhwa's (1994) Feroza is suffered from. Bhaba (1994) cogitates hybridity 'in-between' space between two culture, hence it's the condition of Feroza because she does not belong to any place and as a prey of identity crisis, she decides to settle and makes an adjustment but she is unable to wipe away the notions of her country as Fareed (2013) opines that after adopting and absorbing new culture 'Diasporic people do not forget their past and the recollection of past.

While living in the USA, she notices changes in her conduct. Her speaking and living style undergoes a great change. She starts drinking and dancing at parties. Feroza starts facing identity issues from the time when she goes to the USA. The two main features of postcolonialism namely 
hybridity and Diaspora are reflected through her migration. Does she want to keep hold one identity by losing others or does she satisfy with perplexed identities? It is an important question to investigate. Her resolution of staying in the USA permanently provides the answer to that question. When she comes to Pakistan to meet her family, she feels that she is a misfit in this country and feels herself a stranger in her birth country. Feroza's mother does not allow her to absorb the culture which is opposite to their culture and religion regardless of the fact; she has sent her USA to stay her away from the effects of fundamentalists. Zareen does not assist her daughter when she tries to marry David, a Jewish boy. Finally, Zareen says that she has become 'An American Brat' and she regrets her decision to send her to the USA. In this connection, it is argued that whatever situations experienced by Feroza, Feroza's uncle, Manek, and Zareen reflect the impacts of post-colonialism on the people of South Asia especially on the people of the Subcontinent. Feroza becomes a brat, it means that she becomes a pampered girl who resists when her parents want her to get married. Feroza develops resistance and arrogance with the time living in the USA despite the fact she is a meek, humble, and conservative emigrant belonging to third world nations. But now she is fully changed and is free in her making decision. It is quite clear that in this global world, the cultural and religious disparity occupy a significant place but for settling in developed countries, it is necessary to throw away the array of narrow mindedness to be modern and to keep pace with the world.

The present research beautifully describes the issues that are faced by immigrants in the Western countries especially the immigrants who belong to third world countries. They find differences in cultures which is different from the culture of their native country. Sidhwa (2012). beautifully highlights the culture of America and Pakistan and elaborates the differences.

\section{References:}

Ashcroft, B. et al, (Eds.). (1995). The Post-colonial Studies Reader. New York: Routledge.

Achebe, C. a. (1958). Things Fall Apart. London: Heinemann Educational Books. b. (1960). No Longer at Ease. London: Heinemann Educational Books c. (1960). Arrow of God. New York: Anchor Books. d. (1975). Morning yet On Creation Day. London: Heinemann. e. (1988). Hopes and Impediments. New York-London-Toronto: Anchor Books/ Doubleday.

Bhabha, H.K. (1994). The Location of Culture. London: Routledge Print.

Ben-Yoseph, M. (2005). Longing for home: displacement, memory, and identity. Journal of Prevention \& Intervention in the Community, 30(1/2), 117-125.

Brennan, T. (2008). Postcolonial studies and globalization theory. In: R. Krishnaswamy \& J. C.Hawley (Eds): The post-colonial and the global (pp. 37- 53). Minneapolis: University of Minnesota Press.

Eliot, T.S. (1948). Notes Towards the Definition of Culture, London: Faber and Faber.

Etoroma, E. E. (2006). Finding home. International Journal of Diversity in Organizations, Communities \& Nations, 6(3), 103-110.

Fanon, F. (2008). Black Skin, White Masks. Trans. Charles Lam Markman. London: Pluto Press.

Fareed, S. (2013). Sidhwa's An American Brat: Cultural Assimilation with transitional Identity Journal of Higher Education and Research Society.

Hamid, M. (2007). The Reluctant Fundamentalist. Karachi: Oxford University Press.

Hall, S. \& du Gay, P. (Eds) (1996). Questions of cultural identity. Los Angeles: Sage.

Hussain, N. (1996). On The Writers World. Interview with Bapsi Sidhwa. The Nation.

Imbert, P. (2004). Globalization and difference: Displacement, culture, and homeland. Globalizations, 1(2), 194-204.

Imtiaz, S. (2011). Speaking in Tongues: Conceptualizing Femininities in Sidhwa's An American Brat. American International Journal of Contemporary Research.

Kane, B. (2004). Représentation du diptyque savoir et violence dans la littérature post-Colonial in G.E.L.L (Revue du Groupe d'Etudes Linguistiques et Littéraires), Saint- Louis: Centre de Presse \& de Reprographie - UGB, janv.n ${ }^{\circ} 8$, pp. 46-62.

Kane, C. a. (1962). Ambiguous Adventure (translated from the French by Katherine Woods). London: Heinemann. b. (1995). Les Gardiens du temple. Abidjan: Nouvelle Editions Ivoiriennes.

Kapadia, N. (1962). Expatriate Experience and Theme of Marriage in An American Brat, The Novels of Bapsi Sidhwa.

Sarup, M. (1994). Home and identity. In G. Robertson (Ed.): Travelers' Tales: Narratives of home and displacement (pp. 89-101). London: Routledge. 
Sidhwa, B. (1994). An American Brat. New Delhi: Penguin Books. Print

Varner, I. I. \& Beamer, L. (2011). Intercultural communication in the global workplace. New York: McGraw-Hill. 